\title{
VARIA
}

\section{Pre-Exilic Halakhic Text in Judeo-Spanish from the Cairo Genizah by R. Jacob Canpanton}

\author{
Dotan Arad, Bar-Ilan University, Ramat Gan \\ Shmuel Glick, Schocken Institute, Jerusalem*
}

This article brings to light a unique responsum preserved in the Taylor-Schechter Cairo Genizah collection. Though it does expound upon the halakhic and historic content of the responsum, these do not introduce many innovations, and are not the source of its uniqueness. The singularity of the document is that the text, written in Hebrew letters, is in Castilian vernacular with words and expressions in Hebrew. Whereas in Islamic lands a tradition of halakhic writing in Judeo-Arabic developed (until its disappearance in the late Middle Ages), halakhic writings in a language other than Hebrew or Aramaic were rare in Europe. The responsum was composed, in our estimation, in the $15^{\text {th }}$ century, and is one of relatively few written in Spain in this period that have been preserved. The responsum enriches our knowledge of the language of the Jews while still in the Peninsula, and also sheds light on their religious and cultural life. It was authored by $\mathrm{R}$. Jacob $\mathrm{Ca}[\mathrm{n}]-$ panton, whom we suggest is the father of the well-known scholar R. Isaac Canpanton. Information on R. Jacob is limited, and until now there were no known halakhic writings of his. If our identification is correct, it serves to illuminate further the personality of this Jewish sage.

Keywords: Medieval Castile; Cairo Genizah; Distribution of Profits; Castilian Vernacular; Jacob Canpanton; Responsa; Ribbit.

TeXto haláJICO PRE-EXílico en aLjamía hebraico-Castellana de la Guenizá de El CaIRO POR R. JACOB CAMPANTÓN.-Este artículo da a conocer un responsum único conservado en la colección Taylor-Schechter de la Guenizá de El Cairo. Se edita el texto y se explica el contenido halájico e histórico del responsum, si bien, desde ese punto de vista no contiene muchas innovaciones. Su singularidad radica en que está escrito en castellano en caracteres hebreos. Aunque en la órbita de los países musulmanes hubo un desarrollo de escritos halájicos en árabe judío (hasta su desaparición en un periodo tardío), el uso de lenguas distintas del hebreo o el arameo para contenidos halájicos había sido raro en Europa. Según nuestra estimación, este responsum se compuso en el siglo xv y es uno de los conservados de este periodo. El texto enriquece nuestro conocimiento de la lengua de

\footnotetext{
*dotan.arad@biu.ac.il, glicksh@gmail.com
} 
los judíos en la península, y además arroja luz acerca de su vida cultural y religiosa. El autor del texto es «R. Jacob $\mathrm{Ca}[\mathrm{n}]$ pantón», del que se sugiere que sería padre del conocido R. Isaac Campantón. La información sobre aquél era limitada, y hasta ahora no conocíamos escritos halájicos suyos. Si nuestra identificación es correcta, el texto serviría para arrojar luz acerca de la personalidad de este sabio judío.

Palabras Clave: Castilla medieval; Guenizá de El Cairo; distribución de beneficios; aljamía hebraico-castellana; Jacob Campantón; responsa; ribbit.

This article deals with a Judeo-Spanish responsum written by R. Jacob Canpanton, found in the Taylor-Schechter collection of Cambridge University Library. Linguistically, the text uses the Castilian variety of the $15^{\text {th }}$ century written in Hebrew letters containing Hebrew words and expressions. The responsum deals with the distribution of profits between an investor and an agent (המשתדל) and is unique in several aspects, the first of which is that its author was a Hispano-Jewish sage who eventually wrote it in Judeo-Spanish. The Jewish scholars, both in Spain and throughout the Sephardic Diaspora in the Ottoman Empire, wrote responsa in Hebrew on the main. There have been preserved a number of $16^{\text {th }}$ century Sephardi responsa including texts in vernacular (mainly testimonies, and deeds, ordinances, etc.) that have been the object of recent analysis by several scholars. ${ }^{1}$ However, the halakhic discussion remains in Hebrew. The one presented here is a relatively rare example of a responsum written not in Hebrew but in vernacular Castilian in Hebrew script. Furthermore, this responsum is part of a relatively small collection of sources in Spanish dialects in Hebrew letters that pre-date the expulsions from Spain. Finally, if the proposed identification of the author is correct, it provides with a new and less familiar facet of the character of its author, a Hispano-Jewish scholar about whom we know very little.

Spanish persecution in 1391 sparked a wave of emigration from the Iberian Peninsula. Among the emigrants were famous halakhic authorities such as R. Isaac Perfet, and R. Simon b. Zemah Duran and some

\footnotetext{
${ }^{1}$ See the most recent and comprehensive analysis by A. Benaim, Sixteenth-Century Judeo-Spanish Testimonies. An Edition of Eighty-four Testimonies from the Sephardic Responsa in the Ottoman Empire (Leiden-Boston: Brill, 2012).
} 
of his relatives. Even after that date, halakhic decisors who remained in Spain continued to write answers to queries received. Unfortunately, few of these survived; ${ }^{2}$ one of them is the responsum of R. Jacob Canpanton which follows in this article.

As we know well, most of the documents found in the Genizah were written in Hebrew, Aramaic and Judeo-Arabic. However, there are a number of documents which were composed in other languages, many of them in Judeo-Spanish. These documents undoubtedly testify to the existence of the largest group of immigrants in Egypt in the $15^{\text {th }}$ century and onwards. Among these documents there are literary works, prayer books, homiletic pieces and financial accounts (individual and communal), but the main genre is letters: personal and commercial. ${ }^{3}$ Aside from letters in Judeo-Spanish written in Hebrew script, there are also a few letters in Spanish written in Latin script. Among the documents in Spanish dialects in Hebrew letters which were discovered in the Genizah, this is the only responsum uniquely preserved in this language. The document was apparently copied in Spain and brought to Egypt by an emigrant (or expelled Jew) from the Iberian Peninsula, and preserved in the Genizah. It sheds light on the cultural wealth that the JudeoSpanish emigrants brought with them to the East.

The responsum is written on a single sheet in fluent Sephardic writing. Paleographic evidence as well as the method of transliteration into He-

\footnotetext{
${ }^{2}$ See, for instance, J. Boкsвorm, "Responsa of the Sages of Spain Concerning the Law of the Lethal Woman" (heb.), Moriah 6-7 (1977), 2-11. Other responsa can be found in Shiv'a 'Enayim (Livorno, 1744), 54-68; see also J. SPIEGEL, "Responsa of R. Isaac de Leon to R. Yosef Abudarham" (heb.), Sinai 83 (1978), 181-183.

${ }^{3}$ In recent decades many Judeo-Spanish sources from the Cairo Genizah have been published, in the main by Eleazar Gutwirth. See, for example, E. Gutwirth, "Fragmentos de siddurim españoles en la Guenizá," Sefarad 40 (1980), 389-401; IDEM, "Judeo-Spanish Fragments from Cairo," Anuario de Filología 9 (1983), 219-223; IDEM, "Fragments of Judeo-Spanish Ballads from the Genizah," Jerusalem Studies in Jewish Folklore 5-6 (1984), 71-84; IDEM, "A Medieval Spanish Translation of Avot: Genizah Fragments," Annali. Istituto Universitario Orientale 49 (1989), 289-300; IDEM, "A Judeo-Spanish Endecha from the Cairo Genizah," Mediterranean Language Review 6-7 (1993), 113120; IDEM, "A Judeo-Spanish Planctus from the Cairo Genizah," Romance Philology 49 (1996), 420-428.

${ }^{4}$ See E. Gutwirth, "Letter in Spanish from Gaza" (heb.), in Mas'at Moshe: Studies in Jewish and Arabic Culture in Honor of Moshe Gil, ed. E. FLeISCHER et al. (Jerusalem, 1998), 137-142.
} 
brew letters seems to determine the date of this manuscript to be around the second half of the $15^{\text {th }}$ century.

Additional notes that appear on the page help to date the manuscript. On the upper portion of the page are accounts in Castilian, in Hebrew letters, in which a name, Don Yosef, appears. On the right side are a number of lines that are hard to decipher; at the end of these, a man named Yosef Picho is mentioned, perhaps the same Don Yosef. Below these sections appears an additional four-line text in Castilian, apparently a draft of a commercial letter. The writer notes, among other things, that he had received a sum of 200 florins from Don Abraham to be sent to the city of Valladolid, and additional amounts are noted. This text proves that the document, at least its upper part, was written on Spanish soil prior to the expulsion of 1492. The date 25 Marheshvan appears in the last line, but without the year. Following this is a glossary entry, "copper - called acero in the foreign tongue [la 'az]," and then follows R. Jacob Canpanton's responsum.

\section{R. JACOB CA[N]PANTON}

Who is R. Jacob Ca [n]panton, ${ }^{6}$ author of this responsum? It is possible that he is the same person known as R. Jacob, son of R. Isaac Canpanton, father of R. Isaac Canpanton (d. 1463) who authored Darkhe ha-Talmud, about whom we know very little. Thus, in Sefer Yuhasin, R. Abraham Zacut writes about R. Isaac Canpanton: "The great light R. Isaac Canpanton, son of R. Jacob Canpanton, composed books on mathematics, astronomy and Torah." Biographical information about R. Jacob Canpanton appears in a Sephardic prayer book written in 1439, today kept in the Palatina Library in Parma (no. 2207). ${ }^{8}$ In the Yom Kippur section, the confessional prayer was copied according to the version אשמנו באומר בפועל ['we are

${ }^{5}$ Modern Ladino covre means 'copper' (sp. 'cobre').

${ }^{6}$ The common form of the surname of the author of this responsum is Canpanton, but a shorter form, Capanton, appears in the manuscript before us as well as in other sources.

${ }^{7}$ Sefer Yuhasin ha-Shalem, ed. H. FILIPOwsKY, repr. with an Introduction by A. H. FREIMANN (Frankfurt a. M., 1924), 226.

${ }^{8}$ Mic. 13383 in the Institute of Microfilmed Hebrew Manuscripts (hereafter, IMHM). 
ה' שפתי תפתח ' ['O Lord, open my lips and make my tongue eloquent'] composed by R. Bahya Ibn Paquda. Following the confessional prayer, the editor wrote:

This confession prayer was composed by [...] R. Judah Ibn Tibbon $^{9}[\ldots]$ which I who write here in the Kingdom of Castile saw at the end of the book [Hovot ha-Levavot] when I worked and served my teacher the great Rabbi Jacob Canpanton, may God rest his soul in Paradise [ריתב"ע], in the year 5166 ו'ץ'ין חיים 1406)], ${ }^{10}$ [...] and written here in the first decade [added in the margin: "in the month of"] Av in the year 199 of the sixth millennium [=1439].

According to this, R. Jacob Canpanton was no longer alive in 1439. We know of at least one follower who studied with R. Jacob, R. Hasdai ben Hasdai. In a responsum by the latter published approximately 80 years ago, he mentions R. Jacob as one of his teachers: "From the day I served my teachers, R. Jacob Canpanton and R. Joseph Albo."11

Until now, there were known works by R. Jacob on medicine and the sciences, but none of his halakhic writings. He edited an abbreviated version of the commentary of Solomon Ibn Ya ish on the Canon of Ibn Sina (Avicenna), a manuscript found in the Bibliothèque Nationale de France, ${ }^{12}$ and he also authored the scientific treatise on mathematics Bar Noten Ta'am. A $15^{\text {th }}$ century manuscript of this work is found in the British Library. ${ }^{13}$

${ }^{9}$ This refers to the well-known translator of Provence. The reference here is incorrect; as noted above, the compiler was Bahya Ibn Paquda.

${ }^{10}$ Prov 13:12.

${ }^{11}$ See Y. M. Toledano, "From the Genizahs of the Past - A Responsum by R. Hasdai ben Ḥasdai" (heb.) Mizrah u-Ma'arav 5/2 (5690 [= 1930]), 108-110. R. Hasdai lived eventually in $15^{\text {th }}$ century Spain. His responsum deals with not reciting the Tahanun prayer in the synagogue on the day of a circumcision.

${ }^{12}$ BnF, MS héb.1151 (IMHM, mic. 15108).

${ }^{13}$ BL, MS Or. 1053 (G. Margaliouth, Catalogue of the Hebrew and Samaritan Manuscripts in the British Museum, vol. III [London, 1909], § 1012) (IMHM, mic. 5932). For more on R. Jacob Canpanton, see also the mention by Y. M. ToledAno, "Four Responsa" (heb.), Sinai 12 (1943), 228-229, 235. 


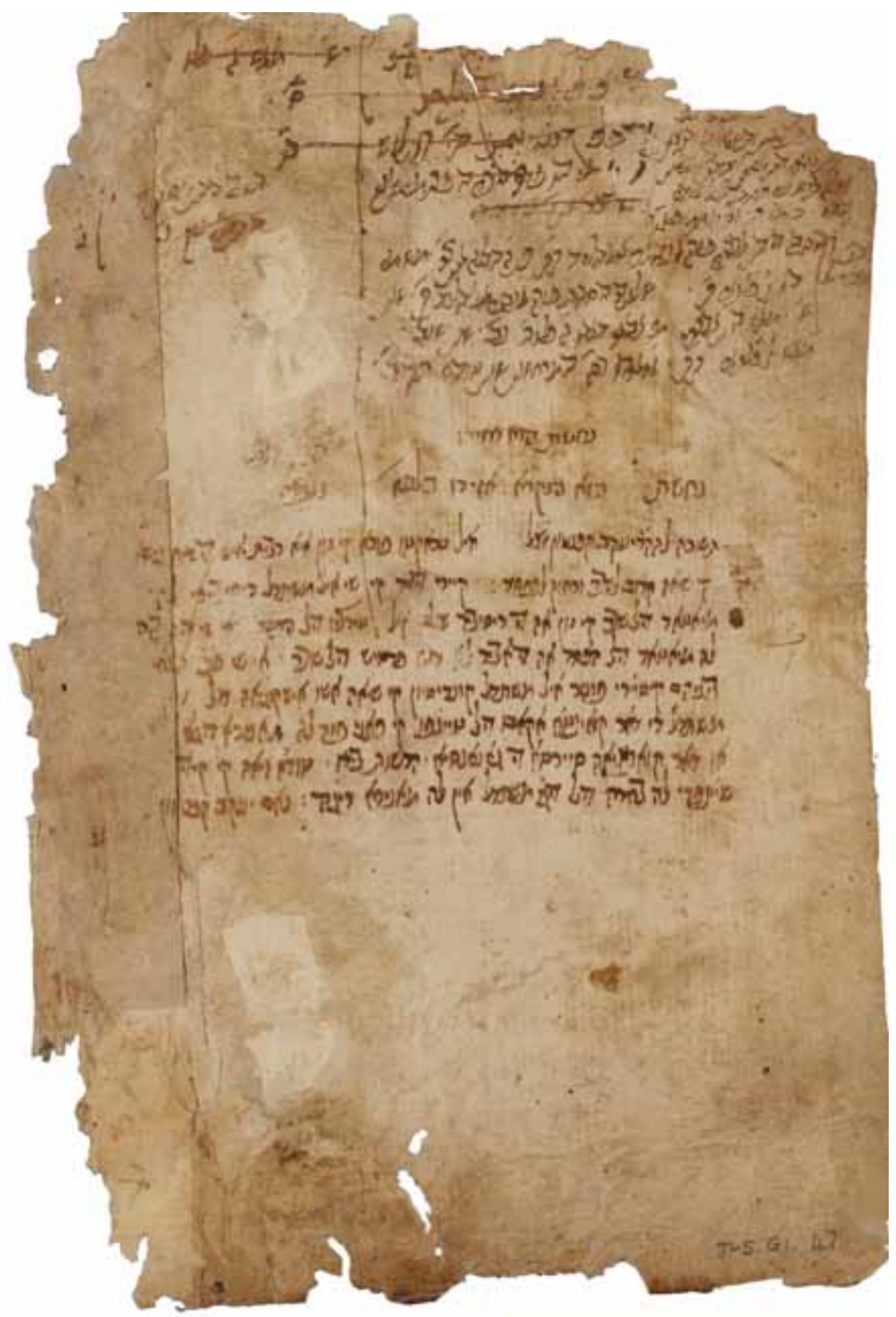

Fig. 1. Taylor-Schechter Genizah Collection (Courtesy of the Syndics of Cambridge University Library).

\section{T.S G. 47.} $\mathrm{cm}$ ins

SEFARAD, vol. 73:2, julio-diciembre 2013, págs. 409-421. ISSN: 00037-0894. doi: 10.3989/sefarad.013.013 


\section{THE TEXT OF THE RESPONSUM}

1 Responsum of the great sage Rabbi טשובה להה"ר יעקב קפנטון זצ"ל. איל איל איל Jacob Ca[n]panton, may the mem- טראקטו פורא קי נון איא רבית אישיש איש איש ory of the just be for a blessing. [In דישטא גישא order] for the contract to entail no interest, it is in this way

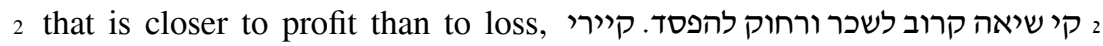
דיזיר קי שי איל משתדל ריסיביירי לה קיה ceive

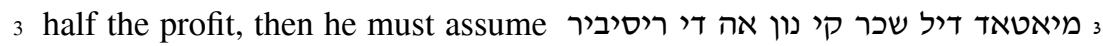
liability for only one third of the שאלוו איל טירציו דיל הפסד איר איר שיר שירי שירי loss. If he will receive

ריסיביירו

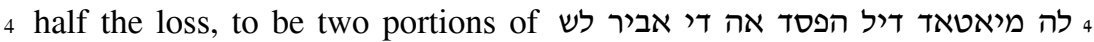
the profit. And if a condition is set דוש פרטיש דיל שכר. אי שי פינגיו תנאיר ליל אירי

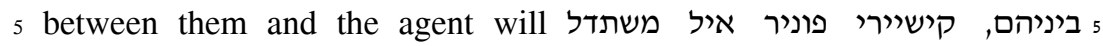

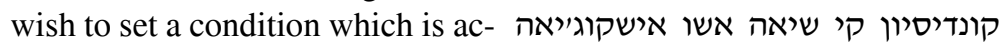
דיל

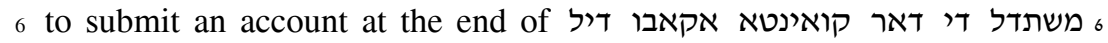
the period for paying in the stated דייניפו קי פאגי לה מאנירא דיג'א manner

7 or give a fixed amount of the profit, ${ }^{17}{ }^{16},{ }^{16},{ }^{7}$ he has the choice, as long as הרשות בידו, טודא ויאה קי קיראי גאנסירי

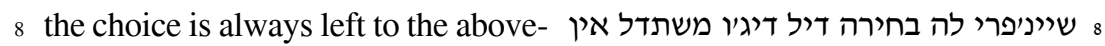
mentioned agent in the above- לא מאנירא דיג'ה. נאם יעקב קפנטון מירון mentioned manner. So stated Jacob $\mathrm{Ca}[\mathrm{n}]$ panton 


\section{Transliteration of the Text}

${ }_{1}$ Teshubah lhh"R. Ya'aqob Ca[n]panton źs’"l. El tracto, pora que non haya ribit, es d'esta guisa: ${ }_{2}$ que sea qarob le-sakhar ve-rahoq le-hefsed; quiere dećir, que si el mishtadel recibiere la ${ }_{3}$ meatad del sakhar, que non ha de recibir salvo el terçio del hefsed; y si recibiere ${ }_{4}$ la meatad del hefsed, ha de haber 1[a]s dos p[a]rtes del sakhar. Y si fecho tenay ${ }_{5}$ benehem, quisiere poner el mishtadel condición, que sea a_su escogiia del ${ }_{6}$ mishtadel de dar cuenta a_cabo del tienpo que pague por la manera dicha ${ }_{7}$ o dar cuantia cierta de ganancia, ha-reshut be-yado, toda-via ${ }_{8}$ sienpre la behirah del dicho mishtadel en la manera dicha. Ne'um Ya'aqob $\mathrm{Ca}[\mathrm{n}]$ panton.

\section{DESCRIPTION OF THE RESPONSUM}

The manuscript of Canpanton's responsum does not contain the question asked; moreover, it is fairly succinct and no sources are brought upon which the answer is based. Thus, the reconstructed question brought here is in the realm of supposition, based on the manuscript.

${ }^{14}$ The term used by Maimonides and the halakhic deciders is mit'aseq ('dealer') (see Maimonides, Hilkhot Sheluhin ve-Shutafin, 6:2, etc. For the term mishtadel ('one who exerts effort') see, for example, the responsa of the Maharshakh (Rabbi Solomon ben Abraham Hacohen), part I, § 15; and part II, § 67; the Maharam (Rabbi Moshe) Alshekh $\S 19$; the Mabit (Moses ben Joseph di Trani), part I, § 144, and others.

${ }^{15}$ The author here summarizes the ruling that arises from the hereafter case (p. 418) brought in Bava Metz'ia 68b; see Tosafot there, beginning with אי פלגא באגר who bring the following objection: "Does the investor foolish to let the agent decide after the fact, i.e., if there is a loss he will say that the investor must bear two thirds of the loss and he, the agent, will receive half the profit, and if there is a profit he will say that he will bear half the loss and receive two thirds of the profit, so effectively the investor will end up receiving only one third of the profit or bearing two thirds of the loss." See also the second explanation which offers a different interpretation of the Talmud; see also the commentary of Rabbenu Hananel brought by the Tosafot.

${ }^{16}$ In Responsa of the Mabit, part III, $\$ 82$ the transliteration is גנאנסייא.

${ }^{17}$ Not necessarily from the profits; rather, the investor will pay a fixed wage to the agent even in the case of a loss, as agreed upon "whether more or less" (according to R. Meir, Bava Metzi 'a 68b). See the Ra'abad (Temim De 'im, § 51): "Our Mishna that states 'his wage as an unemployed worker' speaks on a case that no condition was set." 
It seems that the question concerns two partners seeking to enter into a profit-making venture, who approached R. Jacob Canpanton and asked him to propose an arrangement concerning the profits earned that would satisfy the halakhic prohibition against ribbit, and that would allow for no suspicion of אבק ריבית ('dust of interest'; an indirect extension of ribbit). ${ }^{18}$ The terms of the business deal were apparently as follows: one partner was to invest funds; the other was an agent, in halakhic terms המשתדל or ('the one exerting effort') as called by Canpanton, who was to apply himself and endeavor to generate profits on the invested funds; these profits would be shared between the two. In order for these profits not to be considered ribbit, the sages instituted taqqanot ('rulings') of sharing the profit and loss fairly between the investor and the agent that would not entail violation of the prohibition against ribbit arising from the investor's profits on the transaction.

When the agent assumes total liability for the principal, the investment is regarded as a kind of loan and the resulting profits as interest. Moreover, assumption of all of the risk is a deterrent, for if the investment is lost not only has the agent wasted his time but he is also obligated to reimburse the amount of principal to the investor. On the other hand, if the investor assumes all the risk, the issue of interest is resolved but the investor will be deterred from investing. The solution brought by the sages is that unless otherwise stipulated, the risk is to be shared half and half by the parties ("half a loan and half a deposit"). ${ }^{19}$

This division ostensibly ensures that the profits accruing to the investor on his portion of assumed risk do not fall into the category of ribbit. But this is not sufficient, because even if the profits are shared equally, the agent worked to invest the 'deposit' in return for a 'loan' -in other words, his time and effort on the deposit (the profits of which accrue to the investor) are in effect interest paid on the loan (the profits of which accrue to him). In order to resolve this difficulty, the sages obligated the investor to remunerate the agent for his services and they offered several options for doing so. ${ }^{20}$

\footnotetext{
${ }^{18}$ Henceforth, the term 'interest' is used to include 'the dust of interest.'

${ }^{19}$ See Bava Metzi 'a 104b.

${ }^{20}$ See Maimonides, Hilkhot Sheluhin ve-Shutafin, 6, 8:1-6.
} 
The partners were apparently not scholars and did not have a command of Hebrew, so R. Jacob Canpanton wrote his brief response in Judeo-Spanish, without citing sources and in a commonplace style. However, since the manuscript contains neither the question nor the sources used, one may entertain other explanations of the response. It is conceivable that R. Jacob Canpanton did write a substantiated answer in Hebrew, but that a copy editor chose to shorten and translate it into Judeo-Spanish, as halakhic texts were often translated for the benefit of the wider readership.

In his response, R. Jacob Canpanton chose to employ a formula based on the words of Rava in tractate Bava Metzi'a (68b), who interpreted a business arrangement conducted by one named Rav Ilish. Canpanton seemingly interprets this section according to Rashi. ${ }^{21}$ The Talmud states:

The sons of R. Ilish issued a business deed [contract] stating "half the profits and half the losses." Rava said: R. Ilish is a great man, and he would not have fed to anyone something that is forbidden. So we must say, "if half the profits, then two-thirds the losses; if half the losses, then two-thirds the profits." ${ }^{22}$

Rashi interprets the clauses beginning with the words "half" and "half the losses" as follows:

A. BM (68b): "If half": If the investor receives a profit and assumes liability for more than half the losses, e.g., two thirds, then this does not entail interest - this means that a third is a loan, meaning that R. Ilish assumed only a third of the liability; he is due a third of the profits and receives the excess of that one third as remuneration for his labor on the two thirds deposit.

\footnotetext{
${ }^{21}$ See Rashi as follows; also 69a, on the words אי פלגא בהפסד, although there are also different formulations and methods.

${ }^{22}$ In other words, the children of R. Ilish entered into a business deal [upon which their father was signed], which stated [that the two sides would share] "half of the profits and half of the losses." Rava said: R. Ilish is a great man, and would not let anyone violate a prohibition [against interest]. Thus we must conclude that the contract was abbreviated and should include the word "or," meaning that R. Ilish may choose for himself between "half the profits" [and the other party would be liable for two-thirds of the loss, or he would choose] "half the losses" [and the other party will receive one-third as a wage].
} 
B. BM (69b): "Half the losses": if the deed stipulates "half the losses" this is to say: if R. Ilish, if he wishes, can take two thirds of the profits, and assume liability for half the losses, and this entails his wage -what he takes as additional profit in excess of what is due on the half considered to be a loan. ${ }^{23}$

The responsum here includes two main options (the first is itself divided into two possibilities):

1. Lines 2-4 - the parties may agree in advance on one of the following two options:

a. Lines 2-3 - If there is a profit, the agent and investor will divide these equally, and in the case of a loss, the investor will be liable for two thirds of the loss ${ }^{24}$ and the agent one third.

b. Line 4 - If there is a profit, the agent will receive two thirds and the investor one third. In the case of a loss, it will be shared equally by the two parties.

2. Lines 4-8 - the parties may stipulate the following conditions: The agent will choose between the options above (i.e., half the profit and one third the loss), or will stipulate a fixed sum as a wage for his services.

Upon examination of the second option we see that its conditions are not identical to the case of R. Ilish. There, the agent (R. Ilish) was given the choice between half the profits and liability for two thirds the loss, or two thirds of the profits and liability for half the loss; Canpanton's remedy grants the agent the prerogative of choosing between one of these two formulas, or setting a fixed wage. In other

\footnotetext{
${ }^{23}$ In other words, because R. Ilish was a great man who certainly would be careful to avoid the "dust" [i.e., an indirect extension] of interest, we must read the clause in the deed "half profits half losses" with the word "or," meaning that R. Ilish was given a choice between the two alternatives. He could choose between the first (half of the profits) in which case he would receive half the profits and assume liability for one-third of the losses; and the second (half the losses), in which case he would receive two thirds of the profits and assume liability for half of the losses.

${ }^{24}$ The practical application of this is debated by the rishonim; see: Maimonides, Hilkhot Sheluhin ve-Shutafin, 6:5; Hidushe HaRamban to Bava Metzi 'a 68b, on the words והאי דינא.
} 
words, he does not allow for the reverse condition, of granting the choice to the investor. ${ }^{25}$

Denying the investor the choice does not seem to correspond to Maimonides' opinion, which is that the investor may decide to either pay the agent a fixed payment or share the profits with him. He writes:

The Sages ruled that if one gives money to another to manage [...] but [the investor] does not wish to pay him a daily wage [...], then the agent's wage will be, on the half of the deposit that he is managing, a third of the profit on that deposit. ${ }^{26}$

This statement is further sharpened by R. Abraham b. David de Posquières, the $\mathrm{Ra}^{\text {'abad, }}{ }^{27}$ who rules that in this type of business deal, the investor may choose: he may give the agent a share in the profits, or he may pay him a set wage, according to his preference. ${ }^{28}$

However, upon closer scrutiny, there is no contradiction between R. Jacob Canpanton's ruling and the interpretations of Maimonides and the Ra'abad. The privilege granted to the investor of defining the profit sharing is given only prior to the actual transaction, ${ }^{29}$ before the outcome is known. Otherwise, the investor would always choose the more profitable alternative: if the business deal yields profits, he will

${ }^{25}$ Lines 7-8: "[...] by his choice, and in general the choice is always left to the abovementioned agent."

${ }^{26}$ Maimonides, Hilkhot Sheluhim ve-Shutafim, 6:3.

${ }^{27}$ Temim De im, $\$ 51$.

${ }^{28}$ Ibid.; the Ra'abad writes: "This is the law in the case of a 50-50 share of profit and loss; if he wished to set a wage of one dinar he may, even though his labor exceeds this. The wage can be small or large; it stands at whatever was agreed upon. Our Mishna states that the wage is paid even if it is not stipulated." The Rama (R. Meir Halevi Abulafia; his opinion brought in the Tur, YD, 177) implies the same, where the language of the contract shows that the investor has the upper hand.

${ }^{29}$ See Tosafot in Bava Metzi 'a 68 b on the text beginning with "If half the profits." They based their commentary on Rashi, assuming that the agent has the right to choose the option he wants within a limited time. Even according to the Ra'abad, who discusses the matter of choice between profit sharing and a set wage, and grants that choice to the investor, also sets a time limit on when that choice can be made. Otherwise, there is a suspicion of ribbit (which does not exist in the case where the choice is granted to the agent). 
prefer to pay the agent a wage and keep the profits; if there is a loss, he will prefer to share the profits (which are really losses), leaving the agent with no compensation for his labor and having violated the prohibition against interest. Therefore, it appears that the Rishonim, including Maimonides and the Ra'abad, granted the right of choice to the investor only if set in advance. R. Jacob Canpanton clearly discusses the option of giving this right to the agent upon completion of the business deal, ${ }^{30}$ when the results are known and when there would be a risk of violating the prohibition against interest (in the case of a loss) if the investor were allowed to choose. Canpanton therefore cautions that the prerogative of choice "must always remain with the agent."

In summary, the singularity of this responsum is not due necessarily to its halakhic innovation. While we do not find among the rishonim any opinion that grants the prerogative of choosing the method of profit sharing to the agent, nonetheless, as stated above, it may reasonably be expected that in the case at hand they would agree with R. Jacob Canpanton's ruling.

To date, this responsum written in Castilian is unique, in the Genizah and elsewhere. Moreover, it is the only responsum known to be attributable to R. Jacob Canpanton. ${ }^{31}$

Recibido: $20 / 08 / 2013$

Aceptado: 11/12/2013

\footnotetext{
30 "If they decide to set a condition and the agent wishes to stipulate that he will submit an account at the end of the period to pay in the above-stated manner or give a fixed amount of the profit, he may choose" (italics added).

${ }^{31}$ We would like to thank Rabbi Y. Schwartz, Prof. D. M. Bunis, Prof. J. R. Hacker, Prof. R. Magdalena, Dr. A. Quintana, Dr. D. Hacohen, Dr. N. Gomel, and Mr. H. Carmi, as well as the anonymous readers of Sefarad, for their important and helpful comments. We are grateful to the Syndics of Cambridge University Library and Dr. Ben Outhwaite, Head of the Taylor-Schechter Genizah Research Unit, for granting permission to publish the manuscript.
} 